\title{
CORRESPONDENCE
}



Surveillance of food poisoning and

salmonella infections

F G Miskelly, MRCP, and R Orr, MB. . . . 1069

Primary biliary cirrhosis: an

epidemiological study

W S Hislop, MRCP...

Finger wrinkling after immersion

in water

S M O'Riain, FRCs; D J Williams, FRCS;

G Alvarez, MD.............. 1070

Porphyria cutanea tarda and beta-

thalassaemia minor with iron overload

R W G Chapman, MRCP........... 1070

Laboratory features of pleural

effusions

P P Sutton, MRCP, and S W Clarke, FRCP . 1070

Comparison of continuous and

intermittent papaveretum after

cholecystectomy

J J Church, FFARCS; J G Jones, FFARCS,

and others.................. 1071

Anthropometric and dynamometric

variables and serious postoperative

complications

R W Parnell, FRCP............... 1071

Antibiotics in surgical treatment of

acute abscesses

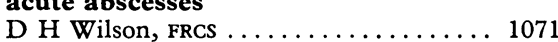

Hazards of surgical glove powders

I D L Fraser, FRCS. . . . . . . . . . . . . . 1072

Breast cancer trials-a new initiative

P A M Walden, MRCP.............. 1072

Parity and breast cancer

E Trapido, $\mathrm{MD} . \ldots \ldots \ldots \ldots \ldots \ldots \ldots \ldots 10 . \ldots$

Mexiletine for supraventricular

tachycardia

S D Slater, FRCPGLAS, and others . . . . . . 1072

Risks of coronary arteriography

C A Layton, MRCP............... 1073

Confusion of filters: potential hazard

from ultraviolet lamps

E F J Ring, Msc, and others... . . . . . . 1073

Driving after anaesthesia

J M Cundy, FFARCS .............. 1073

$A$ rare case of atypical angina

H A Cameron, MB, and others ......... 1073

Vomiting as a diagnostic aid-or

diagnostic pitfall

A M N Gardner, frCs. . . . . . . . . . . . . . . 1074

Women in hospital medicine

Anne C MacLeod, мB............. 1074

Restore the medical superintendent?

S T H Jenkins, FRCP............. 1074

Excluded from practice

A E Ward, MB................... 1074

Two lessons about rabies

D Parker, MRCP.................. 1074

\begin{abstract}
We may return unduly long letters to the author for shortening so that we can offer readers as wide a selection as possible. We receive so many letters each week that we have to omit some of them. Letters must be signed personally by all their authors. We cannot acknowledge their receipt unless a stamped addressed envelope or an international reply coupon is enclosed.

Correspondents should present their references in the Vancouver style (see examples in these columns). In particular, the names and initials of all authors must be given unless there are more than six, when only the first three should be given, followed by et al; and the first and last page numbers of articles and chapters should be included. Titles of papers are not, however, included in the correspondence section.
\end{abstract}

\section{BCG in Britain}

SIR,-Your leading article (27 September, p 825) on BCG in Britain does full justice to the effect of BCG in mass vaccination programmes but barely mentions its importance for contacts; yet it is in this field that BCG has its greatest value and it is in this field that the highest number of individuals are likely to benefit. ${ }^{1}$ Unfortunately, this does not seem to be realised by many doctors today, including some chest physicians-with disastrous results.

Although tuberculous meningitis is very uncommon almost every case that I have had in the last few years would have been easily preventable had the child had BCG. Within the last three years I had two children whose mother, grandmother, grandfather, or any combination had had tuberculosis and yet the child was not given BCG, even when the mother asked. These patients included one whose mother had recovered from tuberculous meningitis in her childhood and yet the child was not given BCG. Another tragedy is that as tuberculous meningitis is now, fortunately, unknown or uncommon, diagnosis is commonly delayed because people do not think of it. Although we have effective treatment to ensure recovery without sequelae in every patient who presents early enough, grave

sequelae can still occur in those who have been in a coma for days before they are referred to a proper centre.

It is essential that BCG should be given to every baby-which could be done on the first day effectively-with a positive family history, even if there are no active cases known at the time; and that BCG should be given to any

contacts of newly discovered cases. By contacts I mean even next-door neighbours and friends, not just relations.

University Department of Paediatrics, Children's Hospital,
Sheffield S10 2TH

${ }^{1}$ Lorber J. Br Med f 1953;ii:1122-6.

\section{Collecting and banking human milk: to heat or not to heat}

SIR, - I wish to disagree with the recommendations of Dr Bengt Bjökstén and others (20 September, p 765) in their paper on collecting and banking human milk.

The essential points in their paper can be summarised as follows: they have seen no ill effects from feeding donated raw human milk to newborn infants; pasteurisation is an inexact process which not only eliminates pathogenic bacteria but also damages the bacteriostatic mechanisms present in human milk; as a result pasteurised human milk will be more susceptible to later contamination; therefore nurseries should use raw breast milk.

These apparently reasonable arguments oversimplify, and in places misrepresent, some of the issues involved. Of key importance is the fact that pasteurisation need not be an inexact and unreliable process. To my knowledge there are at least two commercially available machines specifically designed for the precise heat treatment of human milk. We have shown that such a machine can preserve the majority of the antimicrobial factors while reliably eliminating potential pathogens from pooled banked milk. ${ }^{1}$ The milk is exposed in $100 \mathrm{ml}$ bottles to a temperature of $62.5^{\circ} \mathrm{C}\left( \pm 0 \cdot 5^{\circ}\right)$ for 30 minutes with a rapid and reproducible heating and cooling cycle. Furthermore, the machine is automated and adaptable to other time and temperature settings. Our recent studies (unpublished) have shown that at shorter time and lower temperature settings the bacteriocidal effect is retained with a 